UDC 340 Philosophy

DOI https://doi.org/10.32837/apfs.v0i32.1022

P. D. Guyvan

ORCID ID: https://orcid.org/0000-0003-3058-4767

Candidate of Juridical Sciences, Honored Lawyer of Ukraine,

Professor of Poltava Institute of Business

\title{
TIME AS A CRITERION FOR THE MOVEMENT OF SOCIAL PHENOMENA IN SPACE. FEATURES OF PERSONAL PERCEPTION OF TIME MOVEMENT
}

Problem statement in general. The question "what is time, what is the meaning of this phenomenon" is constantly of interest to scientists, from philosophical to apologists for classical and relativistic physics: they all tried to understand the meaning of time, to understand its nature and essential properties. This aspect is also important for representatives of legal science, although we must state that in the field of its attention this issue does not take up enough space. At the same time, scholars who are concerned with the essential nature of time have long noticed that its purely physical interpretation is quite narrow. In reality, time is somewhat incomparable, more fundamental than the duration, moment or interval than anything that can be expressed by the position of the hands or the position of the lights in the sky [1, p. 112]. Addressing the universal process and taking into account social and cultural development, we should talk about the existence of time as a regulator of social relations, which has elements of historical, social and individual.

The accuracy of a person's perception of time depends on a number of factors. For example, time, which is filled with interesting and colorful impressions, seems to us to be too fast. In turn, when a person retrospectively recalls these events, they seem very long. Instead, being, which is not filled with bright deeds, is presented as a long process, while mentions of it are quite short [2, p. 18]. It is also proved that the conditions of professional and creative activity of a person affect his temporal perception. In particular, the complication of the nature of actions contributes to a significant underestimation of time intervals, and vice versa. The dependence of temporal perception on the emotional sphere of the perceiving subject has also been established. Not the same perception of time is inherent in people of different ages. This is manifested, for example, in different relations to such temporal categories as past, future, eternity. Young people are much more forward-looking, and older people are much more focused on the past, and their actions are retrospective.

Analysis of recent research and publications on this topic. Scientists such as E. Husserl, I. Newton, A. Einstein, M. Berdyaev, M. Trubnikov, K. Levin,
I. Kant, A. Bergson, V. Vernadsky, B. Ananiev, N.Mole, E. Tregubov, and others studied the objective course of time, its inseparable connection with the phenomena of the material world and the subjective perception of this process in science. They conducted a detailed analysis of the physical properties of time, its forms, including the subjective perception of temporal manifestations and its relationship with conscious and subconscious reflections. But the question cannot be considered studied. After all, along with the movement of the process of cognition, there is also the movement of the object itself - time. Therefore, doctrinal studies of the relationship of time with other natural phenomena are currently underway, and the characteristics of the interaction of various temporal aspects are being studied. This is essential for identifying individual manifestations of the relationship of different time states. The aim of this scientific article is to study the essential approaches to the effectiveness of such interaction, which, in the end, determines the essence, the quintessence of time, in particular, in the field of legal relations.

Presentation of the main material of the study. Subjectively, each person, being during certain periods of the general time course as an observer of specific phenomena, has his own unique temporal idea of the duration of individual events, their connection with other phenomena, sequence and variability. At the same time, one of the most pressing problems of time is its adequate and correct measurement. After all, to answer the question of what time is is, in fact, the same as to determine the problem of measuring it. In any case, this is the root or essence of time [3, p. 400]. Time is traditionally understood as an "attribute", a general form of matter, which is manifested in the duration of such existence and the sequence of changes in the states of all material systems and processes in the world $[4$, p. 15]. It has been perceived differently by people over the centuries. The cyclical change of seasons, time of day, etc. was associated with the turnover of time periods in a circle as a manifestation of the eternity of the time rhythm. When the means of accurate time measurement was invented by fixing it at regular intervals, an important step in temporal certainty was. The consequence of this discovery 
was the transition in the awareness of time from its cyclical perception to the understanding of temporal progress as a straight line of events that runs from past to future through certain coordinates that have the name of the present. This allowed for a clear distinction between the categories of past and future, providing each of them with an appropriate set of attributes. At the same time, moving from cyclical to linear manifestation, time ceased to be perceived as a substance subject to man. After all, the initial and final moments of the time course acquired an indefinite (infinite) character, which gave it the opportunity to flow regardless of the will of the people. As a result, people began to realize that they could not influence the objective passage of time, but only had to obey it.

Firstly, the question of being, its forms, properties and structure, including space, time, motion, has been studied within the ontology, the branch of philosophy that studies the fundamental principles, the general categories of being. Ontology tries to make a general outline of the phenomena existing in nature, thus not being reduced to developments of separate sciences. One of the main categories that characterize a certain phenomenon in the ontology as real, objective and independent of human consciousness is the concept of matter. Matter as a philosophical category is perceived not because of its individual specific properties, but because of the general, comprehensive and abstract nature of its manifestations. It does not contain any definite features, but is only the result of abstract human thinking.

With the further development of science, the theory of idealism became widespread, emphasizing the subjective and figurative reflection of being in the human mind. The basic idea here was that ideal perception forms in the mind essential differences between an object and its imaginary image. An image does not have all the physical properties of a particular object, because it is devoid of corporeality, it is not material. Therefore, space and time were imagined as ways of arranging matter through cognition, so they have a psychological origin. Time was perceived as a psychological fact, the inner experience of the human soul. Such an approach characterized the study of the French philosopher A. Bergson, who analyzed time in the context of its experience by man as a living conscious being. The essence of such a subjective and irreversible time was determined by the scientist exclusively through the category of duration. Since duration is the course of a person's inner life, the only carrier of time will be the subject. Therefore, our feelings about real material phenomena, reflected in the internal duration, and create the time of the external world [5, p. 40-41].

We must state that there are serious difficulties in the process of cognition of time. At first glance, it would seem that time is an everyday, largely everyday category that is familiar and commonplace in our lives. However, his more meticulous study with the identification of characteristic features and propertiesinevitably encounters obvious difficulties: time is not subject to detailed consideration, like other properties of objects. There are signs of problems, both objective and subjective. The first is the place of observation of the phenomenon under study. Man and any of his actions, including the laws of building social relations, various legal and customary acts, can not remain beyond time. They are not outside certain actions that take place in space, and with them, regardless of whether a particular subject is a participant or not, travels in time. A single theory of time has not yet been developed, there is no precise philosophical and scientific definition of time, which would essentially cover all its characteristic properties. For now, let's try to explore the achievements of science in the field of research and evaluation of temporal manifestations of matter. It should be noted that the absolute truth in this matter has not yet been reached. One of the main problems that science is concerned with is the development of a single system of accounting, measurement or calculation of time, which would correspond, firstly, to its real content, and secondly, would be quite convenient and universal for various scientific observations. A serious task of modern science is to further focus on the study of time at the level as it is now given to the study of matter and energy that fill space.

Man is aware not of time itself, but of its movement, change. It is because of the change in time observed by the subject that its definition has been given in the literature. Thus, S. Askoldov pointed out that change is the root or essence of time. Such a change expresses in human perception the unity of past, present and future, and this unity occurs only in consciousness or through consciousness. Change or, what is the same, time is first of all a state of the soul, it is the so-called psychological time, which has its individuality, subjectivity and in this sense relativity [6, p. 81-82]. Indeed, the understanding of the concept of time and its flow arose in man during his social life, thus defining the collective nature of time as a rhythm. Time is closely connected with all human activity, both physical and intellectual, it is manifested in the influence of the past on the present and future, in connection with time and true existence, but most characterizes human activity for the future.

Scientific studies of time and its properties can be linked to Newton. He introduced the concept of absolute time - a constantly changing direction in the direction of the future, which is homogeneous and the same at all points in space. This rule was postulated at the axiomatic level, ie it was introduced without evidence. This time is a conditional 
reference social time, specially created by mankind for the rational organization of social life. It flows evenly and consistently, it is impossible to control it. Researchers who do not consider the Newtonian absolute time adequate to modern requirements for temporal ways of mediating real life, as one of its main shortcomings note the removal from the process of cognition of the person of the observing subject. This deprives the possibility of knowing the world through personal connection with it, which leads to distortion of knowledge. Therefore, there are certain problems in calculating and establishing the temporal characteristics of an object in these areas of research, because our ideas about absolute time do not agree with reality: time is much more closely related to various factors that determine the existence of bodies in space. usually postulated. At the same time, such a temporal notion is quite sufficient to solve the tasks set by law, and in particular civil law: it is the absolute time and objective laws of its course that mediate the development of material legal relations in society.

Historically, the concepts of time in science have developed within certain directions, which, having different basic foundations and based on certain evolutionary ideas about time during the development of knowledge of nature, proceeded from different principles of the nature of motion as a category of time. Thus, the concept of substance uses the concept of time as a certain special kind of substance that objectively exists in nature along with space, matter, and so on. As an independent natural phenomenon, time can in some way affect the objects of the real world and the various processes that take place in it. Based on the classical laws of nature, the interaction of individual components in space (substances) is related. In other words, the inverse effect of the state of material objects and certain characteristics of processes in space on the properties of time is also possible.

An important place in the study of time is the conceptual definition of the ratio of the sequence of events in time, which is the quintessence of temporal causal relationships in all manifestations of human life, including social relations governed by law (legal relations). In this case, the essential interactions in the temporal relationship between the phenomena of the objective world are not as linear as it seems at first glance. Indeed, if we go from the opposite, the fact that a certain event occurred after another, does not mean that it was due to the latter. Here, the logical error set forth in the postulate growth hoc, ergo propter hoc (after that, therefore, caused by this) is clearly manifested, which consists in accepting the time sequence as a causal relationship. This approach, with some assumptions, would be acceptable when examining the category of simultaneity: if events occur simultaneously, there can undoubtedly be no causal relationship between them. On the other hand, of course, another thesis will be true, which can be briefly defined as propter hoc, ergo growth hoc (caused by this, then after). The presence of a causal relationship between the phenomena clearly indicates that the cause of the event will occur earlier than the cause (the order of events in time will be established). In principle, we can agree with the thesis of the proponents of relativistic theory that the concept of causality is still too narrow for a general justification of the order and sequence of manifestations of matter in time, any phenomenon is caused by a set of factors, and distinguish some as "causes" and others not to consider in this plane there are no sufficient bases [7, p. 132].

In the process of his activity, a person is able to set specific micro- and macro time intervals quite accurately. This is done by using a reflex based on established skill processes that are complicated by acquired temporal extrapolation. This subconscious ability, modeled and compared with the ability of man to consciously estimate time, is the ability to apply temporal manifestations, measured by man, and extrapolate them to real relationships occurring in space. On the other hand, if we consider the subjective side of perception, each person, being for certain periods of time as an observer of specific phenomena, has its own unique temporal idea of the duration of individual events, their relationship to other phenomena, sequence and variability.

Surprisingly, one of the most pressing problems of the time is its adequate and correct measurement. After all, to answer the question of what time is is, in fact, the same as to determine the problem of measuring it. And, since matter is described by the laws associated with its motion, the essence of temporal progress also has similar principles. Aristotle also pointed out that time is the number of motions [8]. The founder of the scientific theory of classical mechanics, Newton, in his Mathematical Principles of Natural Philosophy, makes a conceptual assumption of a world consisting of space and time and material objects moving in space and time. These two environments act as a huge allencompassing stage on which actions take place - the phenomena of the material world. These phenomena are transient. However, even if they disappear, the scene remains and other objective realities in its movement will reappear on it. Space and time are entities independent of matter - substances. In this case, the scientist operates with the concept of absolute time, which he defines as a phenomenon that exists in itself and in its essence, regardless of the interaction with something external, which emerges evenly and, in other words, is called duration. Absolute time, as already mentioned, cannot be changed in its course, the same length and the same state correspond to the properties of all things, regardless of whether they move or are at rest, and regardless of the speed of 
natural bodies and their position relative to each other [9, p. 22]. The main provisions of classical mechanics regarding the reproduction of the flow of absolute time are firmly entrenched in the practical mediation of various temporal phenomena. At present, it is practically identified with the idea of real time. Thus, this system-forming mechanism as an adequate idea aimed at understanding time and space, quite decently explains specific practical situations and is widely used in applied fields of various sciences, including law.

According to this thesis, the mediation of the laws of existence and progress of this substance can, in principle, be mediated by the rules relating to matter. Instead, the relational concept defines time as a relative phenomenon that establishes proportionality between different events (from the Latin relativus - relative). In this scientific approach, time is not a separate independent phenomenon, but is only derived from certain relationships of things and processes with each other. Depending on the chosen reference criterion the specified system of relations is formed also. One of the main principles of the relational concept of time is positioned the category of simultaneity. One of the classics of this theory, Albert Einstein, illustrated its meaning in this way: "We must pay attention to the fact that all our judgments, in which time plays a role, are always judgments about simultaneous events. If, for example, I say "this train arrives at 7 o'clock", it means approximately that the indication of a small hand on my clock at 7 $o$ 'clock and the arrival of the train are simultaneous events. The time of events is a simultaneous display of a fixed clock, which is in the place of the event $[10$, p. 8,10$]$. However, the concept of simultaneity will no longer be applied if the observation is not conducted from one coordinate system, but when one of them moves relative to another. The so-called principle of horizon incompatibility should also be taken into account: different subjects cannot have the same features at the same time [11, p. 206].

When the ratios within the system change (distances, masses, directions of movement of bodies, etc.), the time scale also changes. Moreover, as proved by Albert Einstein, such patterns are general in nature, including the mathematical regulation of actual interactions by the methods of classical mechanics. Thus at application of the specified regulatory toolkit time depends on character and speed of movement of bodies much more difficult, than by rules of the special theory of relativity at identical set values of unknown search quantity of time. The above-described scientific ideas of philosophy and physical science about space and time can not be considered only the achievements of "pure" physics, they certainly had a significant impact on other areas of knowledge. Despite the different starting points, these scientific approaches often complemented each other. Recently, in various spheres of social, scientific activity, and branches of management, issues of temporal organization have become increasingly constructive and global. In the process of development of special sciences there is a broader analysis of time not only in terms of its physical interpretation as a form of natural processes. The problem acquires an intersectoral character and moves to a new, qualitatively higher level

From the above we can draw certain conclusions. An individual, performing certain functions as a member of the community, conducts its activities in time, social relations of different institutions also have temporal characteristics. As participants in various relationships in society and with each other, people not only know but also use time differently. Thus, we can talk about the need and importance of human influence on the process of learning about nature through its connection with it.Cognition of the world around a person occurs primarily through the definition of the essence of such categories as space and time. In this case, of course, time as a phenomenon of environmental existence is a complex and multifaceted element, which is significantly related to the specific characteristics of objects of observation, such as distance and speed within each inertial system, and depending on the order and principle of measuring real time may differ significantly from the absolute. However, despite the perception of this fact by scientists around the world, the error at speeds of inertial motion, far from the speed of light, is quite small. Thus, based on the greater simplicity of absolute time and ease of use, the associated mechanism is widely used in systems of not very precise sciences and everyday life. In this case, absolute time is used quite successfully as the simplest model of real temporal application.

\section{References}

1. Trubnikov N.I. Problems of time in the light of philosophical worldview. Вопросы философии. 1978. № 2. P. 111-121.

2. James W. Psychology. Moscow : «Педагогика». 1991. $368 \mathrm{p}$.

3. Askoldov S.A. Time is ontological, psychological and physical. At the turning point. Philosophical discussions of the 1920s. Moscow : Политиздат, 1990. 528 p.

4. Abasov A.S. Space. Time. Cognition. Baku : Elm, 1986. 122 p.

5. Bergson A. Duration and simultaneity. Trans. with fr. Petersburg : ACADEMIA, 1923. 154 p.

6. Askoldov S. Time and its overcoming. Мысль, 1922. No. 3. P. 80-97.

7. Molchanov Yu.B. Four concepts of time in philosophy and physics. USSR Academy of Sciences, Institute of Philosophy. Moscow : Наука. 1977. $191 \mathrm{p}$.

8. The teachings of Aristotle. URL: https://pidruchniki.com/15100827/prirodoznavstvo/ uchennya_aristotelya. 
9. Newton I. Mathematical principles of natural philosophy. Translated from Latin and notes by A.N. Krylov. Moscow: Nauka, 1989. 688 p.

10. Einstein A. On the electrodynamics of moving bodies. Collection of scientific works in 4 volumes. T. 1. Moscow, 1965. P. 7-35.

11. Husserl E. Ideen zu einer reinen $\mathrm{Ph}$ nomenologie und ph nomenologischen Philosophie. Zweites Buch: $\mathrm{Ph}$ nomenologische Untersuchungen zur Konstitution. Gesammelte Werke (Husserliana), Bd. IV. Den Haag, 1952. $483 \mathrm{p}$.

\section{Анотація}

Гуйван П. Д. Час як критерій руху суспільних явищ у просторі. Особливості персональної перцепції часового руху. - Стаття.

Стаття присвячена науковому дослідженню питання про сутність і зміст часового поступу в природі, який стосується як суспільних взаємин, так і сфери пізнання різних сторін буття, що нас оточує. Наголошується, що питання часу має досить вагоме світоглядне значення, адже час у людському сприйнятті є тим явищем, яке характеризується особливою емоційністю усвідомлення як фактор, що зумовлюе тимчасовість нашого перебування на землі. Час є тим всеохопним чинником, який дозволяє виявити сутнісний зв'язок подій і явищ, що відбуваються в просторі, надавши їм належної перцепції щодо місця в системі взаємодій різних явищ конкретної взаємодії в просторі. У роботі акцентується, що темпоральні питання завжди мають розглядатися у взаємовідношенні з просторовим, ця взаємодія завжди була важливим елементом вивчення світу. Досліджене онтологічне бачення темпоральних процесів, за яким матерія сприймається не через окремі її властивості, а через загальний, всебічний та абстрактний характер своїх виявів. Це означає, що час, за цією теорією, має суб'єктивний вияв, що відтворюється у відчуттях та переживаннях конкретної людини щодо реальних матеріальних явищ, відображених у внутрішній тривалості, що і створюе час зовнішнього світу. Визначено, що час $є$ властивістю самого буття, його онтологічним атрибутом, якщо об'єкт переміщується в просторі, то він, безумовно, також переміщується в часі. У роботі зроблено висновок про наявність серйозних труднощів у процесі пізнання часу: час має тісніший зв'язок із різноманітними чинниками, що зумовлюють існування тіл у просторі, ніж це постулюється. Зазначено, що дослідження темпоральних властивостей історично відбувалося в межах уявлень про час як абсолютне й однорідне явище, що має однакові параметри в усіх точках простору, що не зовсім точно відтворює реальну картину буття. Насправді, більшість точних наук оперують поняттям реального часу, який концептуально обгрунтовується тезою А. Ейнштейна, що час $\epsilon$ нерівномірним, багатонаправленим, багатомірним та залежить від властивостей системи обліку й руху матерії. Виходячи з більшої простоти абсолютного Ньютонівського часу та зручності користування, пов'язаний із ним механізм доволі успішно використовується як найпростіша модель реального темпорального застосування.

Ключові слова: абсолютний час, перцепція часу, темпоральні фактори.

\section{Summary}

Guyvan P. D. Time as a criterion for the movement of social phenomena in space. - Article.

This article is devoted to the scientific study of the essence and content of temporal progress in nature, which concerns both social relations and the sphere of knowledge of various aspects of life around us. It is emphasized that the issue of time is very important worldview. After all, time in human perception is a phenomenon that is characterized by a special emotional awareness as a factor that determines the temporality of our stay on earth. Time is the all-encompassing factor that allows to make an essential connection of events and phenomena occurring in space, giving them a proper perception of their place in the system of interactions of various phenomena of a particular interaction in space. The paper emphasizes that temporal issues must always be considered in relation to the spatial, this interaction has always been an important element in the study of the world. An ontological vision of temporal processes has been studied, according to which matter as a philosophical category is perceived not through its individual specific properties, but through the general, comprehensive and abstract nature of its manifestations. This means that time, according to this theory, has a subjective manifestation, which is reproduced in the feelings and experiences of a particular person about real material phenomena, reflected in the internal duration, which creates the time of the external world. It is determined that time is a property of being itself, its ontological attribute, if an object moves in space, then, of course, it also moves in time. The paper concludes that there are serious difficulties in the process of cognition of time: time is much more closely related to various factors that determine the existence of bodies in space than is usually postulated. It is noted that the study of temporal properties has historically taken place within the notions of time as an absolute, homogeneous phenomenon that has the same parameters at all points in space, which does not exactly reproduce the real picture of life. In fact, most exact sciences operate with the concept of "real" time, which is conceptually substantiated by the thesis of A. Einstein that time is uneven, multidirectional, multidimensional and depends on the properties of the system of accounting and motion of matter. But, based on the greater simplicity of absolute Newtonian time and ease of use, the associated mechanism is used quite successfully as the simplest model of real temporal application.

Key words: absolute time, time perception, temporal factors. 